\title{
Detection of anti-Toxoplasma gondii antibodies in experimentally and naturally infected non-human primates by Indirect Fluorescence Assay (IFA) and indirect ELISA
}

Detecção de anticorpos anti-Toxoplasma gondii por meio das técnicas de Imunofluorescência Indireta e ELISA Indireto em primatas experimentalmente e naturalmente infectados

Andréa Bouer ${ }^{1,2 *}$; Karin Werther²; Rosangela Zacarias Machado²; Andréa Cristina Higa Nakaghi²; Sabrina Epiphanio³; José Luiz Catão-Dias ${ }^{3}$

${ }^{1}$ Faculdade de Medicina Veterinária, Universidade de Cuiabá - UNIC

${ }^{2}$ Departamento de Patologia Veterinária, Faculdade de Ciências Agrárias e Veterinárias, Universidade Estadual Paulista - UNESP

${ }^{3}$ Departamento de Patologia, Faculdade de Medicina Veterinária e Zootecnia, Universidade de Sáo Paulo - USP

Received May 12, 2009

Accepted August 12, 2009

\begin{abstract}
The Indirect Fluorescence Assay (IFA) and the indirect ELISA were comparatively used to detect IgG and IgM antibodies for Toxoplasma gondii in experimentally and naturally infected primates. In the experimentally infected group, antibodies of diagnostic value were detected at day 9 post-infection (PI) with the IFA (IgG and IgM) and with IgG-ELISA. IgM-ELISA detected antibodies for T. gondii starting at day 3 PI until the end of the experiment (102 days PI). Of the 209 naturally infected sera tested, from many zoos of State of Sao Paulo, 64.59 and $67.94 \%$ were positive in the IgG-IFA test and IgG-ELISA respectively. IgM-ELISA test detected seropositivity in $52.63 \%$ of the sera although IgM-IFA test detected it in only in $0.96 \%$ of the samples. The differential toxoplasmosis diagnosis was accomplished with Neospora caninum by IFA, observing 61 (29.2\%) seropositive animals for this parasite and $149(70.8 \%)$ negative. Sixty animals were positive for both T. gondii and N. caninum. Pneumonia, splenomegaly, and intestinal ulcers were macroscopically observed. Unremarkable interstitial pneumonia, enteritis, colitis, splenitis, and glomerulitis were microscopically observed. The immunohistochemical stain could not detect the presence of $T$. gondii in the tissues of the animals infected experimentally.
\end{abstract}

Keywords: Toxoplasma gondii, toxoplasmosis, primates, Indirect Fluorescence Assay, ELISA.

\section{Resumo}

Detectou-se anticorpos das classes IgG e IgM anti-Toxoplasma gondii em primatas experimentalmente e naturalmente infectados, utilizando-se como técnicas comparativas a RIFI e o ELISA-teste. No grupo dos primatas experimentalmente infectados, anticorpos de valor diagnóstico foram detectados a partir do $9^{\circ}$ dia de infecçáo tanto na RIFI (IgG e IgM) como no ELISA-IgG. O ELISA IgM detectou anticorpos a partir do $3^{\circ}$ dia de infecção até o final do experimento (102 dias pós-infecção). Dos 209 soros dos primatas naturalmente infectados, de diversos zoológicos do Estado de São Paulo, 64,59 e 67,94\% mostraram-se positivos na RIFI-IgG e no ELISA-IgG, respectivamente. O ELISA-IgM detectou soropositividade em $52,63 \%$ dos soros ao passo que a RIFI-IgM detectou apenas 0,96\%. Foi realizado também diagnóstico diferencial para Neospora caninum, através da RIFI, observando-se 61 (29,2\%) animais soropositivos para este parasita e $149(70,8 \%)$ animais negativos. Sessenta animais foram positivos para T. gondii e N. caninum. Pneumonia, esplenomegalia e úlceras intestinais foram observadas macroscopicamente. Pneumonia intersticial, enterite, colite, esplenite e glomerulite foram os achados microscópicos. A imunoistoquímica náo revelou a presença do T. gondii nos tecidos dos animais experimentalmente infectados.

Palavras-chave: Toxoplasma gondii, toxoplasmose, primatas, Imunofluorescência Indireta, ELISA. 


\section{Introduction}

Toxoplasmosis is a zoonosis caused by Toxoplasma gondii, an obligate intracellular parasite that is attracting increased attention of investigators due to the severity of the congenital form in humans and in other species. The definitive hosts of the parasite are domestic cats and other felids, although many mammals and birds can become intermediate hosts (DUBEY, 1986; EPIPHANIO et al., 2000).

Species from zoos are more susceptible to acquiring the disease due to the stress of captivity in conjunction with the proximity with wild and domestic felids that may be eliminating oocysts in feces, and receiving raw or undercooked meat with the presence of tissue cysts (DUBEY; BEATTIE, 1988). There is also the possibility for the dissemination of the disease in zoos due to equipment used concurrently in felid and monkey cages, such as gloves, boots, rubber hoses, and brooms (DUBEY, 1986).

New World primates are highly susceptible to toxoplasmosis and, for unknown reasons, rarely survive the illness (DUBEY, 1986; CARME et al., 2009). The first case of toxoplasmosis in primates was reported by Theze, in 1916, in French Guiana. After that many cases have been reported in several countries, but in the last years the number of cases of toxoplasmosis in New World primates has increased, as observed by some authors (DIETZ; HENRIKSEN, 1997; PERTZ; DUBIELZIG; LINDSAY, 1997; BOUER et al., 1999; EPIPHANIO et al., 2000; EPIPHANIO et al., 2001; EPIPHANIO et al., 2003; CARME et al., 2009; SALANT et al., 2009), with the presence of several outbreaks in Brazilian zoos since 1995. SILVA et al. (2001) studied the seroprevalence of T. gondii in captive neotropical felids also from Brazil, by the modified agglutination test.

Based on the frequency of reported cases and on experimental studies, it is believed that New World primates are much more susceptible to toxoplasmosis than Old World primates (DUBEY; BEATTIE, 1988; CUNNINGHAM et al., 1992; ANDERSON; McCLURE, 1993), although the reason for this high susceptibility remains unknown (CUNNINGHAM et al., 1992).

Due to nonspecific clinical signs, diagnosis of toxoplasmosis is difficult in animals. The signs, which may easily be confounded with those of other diseases (neosporosis, sarcocistosis, leptospirosis), make laboratorial diagnosis necessary.

Many serologic tests have been performed by several investigators in an attempt to demonstrate which is the most effective in the diagnosis of toxoplasmosis (ISHIZUKA; MIGUEL; BROGLIATO, 1974; CALAMEL; LAMBERT, 1985; DUBEY; KRAMER; WEISBRODE 1985; VIDOTTO, 1992).

In this context, the objectives of the present work were to study the humoral immune response of primates experimentally infected with $T$. gondii by the ELISA test and IFA. We also aimed to study the macroscopic and microscopic lesions caused by the parasite, and to determine the seroprevalence of $T$. gondii in captive primates of Sao Paulo zoological parks.

\section{Materials and Methods}

\section{Toxoplasma gondii strain}

The $T$. gondii strain ( $\mathrm{N}$ strain, type II), available at the Immunoparasitology Laboratory of Faculty of Agricultural
Sciences and Veterinary (FCAV)-UNESP, was obtained from the Ribeirão Preto Medical School, University of São Paulo, and is being maintained through successive passages in Swiss webster mice from the Central Animal House of UNESP. The tachyzoite suspension was obtained using the methodology described by Domingues et. al 1998, and it was used as an antigen for IFA and for the preparation of a soluble antigen for indirect ELISA. The tachyzoite suspension $\left(10^{7}-10^{8} / \mathrm{mL}\right)$ in $0.85 \%$ saline solution was submitted to 11 cycles of freezing $\left(-70^{\circ} \mathrm{C}\right)$ and thawing in a water bath $\left(37^{\circ} \mathrm{C}\right)$. The final suspension was centrifuged at $17000 \mathrm{~g}$ for one hour at $5^{\circ} \mathrm{C}$ and the supernatant was collected, aliquoted, and stored at $-20^{\circ} \mathrm{C}$ until use. The protein concentration of the soluble antigen was determined using the Hartree method (1972).

\section{Animals (Instituto Brasileiro do Meio Ambiente e dos Recursos Naturais Renováveis-IBAMA process n. 020068/98-38 and ethical protocol $n .027196$ in FCAV-UNESP)}

Experimentally infected: five adult monkeys (Cebus apella), clinically healthy and presenting negative serologically for $T$. gondii and for Neospora caninum, were experimentally infected with a tachyzoite suspension $\left(1 \times 10^{5} / \mathrm{mL}\right)$ by the intraperitoneal route. Clinical examination and full blood count were performed during all experimental infection. Before inoculation, during a period of three months three blood collections were performed in order to obtain the sera. During the 102 days following infection, blood was collected from the jugular or femoral vein on the following days: $3^{\text {rd }}, 5^{\text {th }}, 9^{\text {th }}, 13^{\text {th }}, 31^{\text {st }}, 45^{\text {th }}, 66^{\text {th }}, 83^{\text {rd }}$, and $102^{\text {nd }}$. Positive control serum samples were obtained from the three infected monkeys and negative control serum samples were obtained from the control animals $(\mathrm{n}=2)$ and also from monkeys of different zoos. Naturally infected: 209 serum samples were obtained from 16 species of primates from 14 zoos in the state of São Paulo (latitude $21^{\circ} 49^{\prime} 47^{\prime \prime} \mathrm{S}$ and longitude $49^{\circ} 12^{\prime} 27^{\prime \prime} \mathrm{W}$ ).

\section{Indirect Fluorescence Assay (IFA)}

The IFA was performed as per as Camargo, Moura and Leser (1989). Two different conjugates were used: an anti-monkey IgG (Sigma Co., St. Louis, USA) at a 1:32 dilution and an anti-monkey IgM (KPL Inc., Gaithersburg, USA) at a 1:200 dilution, labeled with fluorescein isothiocyanate, both in phosphate buffered saline (PBS) containing 0.01\% Evans Blue. The slides were examined under a fluorescence microscope (epi-illumination system) using a 40x objective (Olympus BX60 - Olympus America Inc., Florida, USA). The highest serum dilution at which fluorescence was detected in the whole protozoa outer membrane was taken as a final end point. Sera at a 1:40 dilution or higher were considered positive.

\section{Indirect Fluorescence Assay (IFA) for Neospora caninum}

This procedure was performed as recommended by the manufacturer (VMRD, Inc., Pullman, USA), for the use of slides with $N$. caninum antigen. The sera were used at a single dilution (1:50) and the conjugate was the same as described above for T. gondii IgG-IFA, at a 1:32 dilution. 


\section{Indirect ELISA}

Optimum antigen solution and positive, negative, and conjugated sera were determined through end block titration. One hundred microliters of antigen (at concentration of $10 \mu \mathrm{g} \cdot \mathrm{mL}^{-1}$ for IgG-Elisa and $5 \mu \mathrm{g} \cdot \mathrm{mL}^{-1}$ for IgM-Elisa) diluted in $0.05 \mathrm{M}$ sodium carbonate-bicarbonate buffer, $\mathrm{pH} 9.6$, were added to each microplate well and the plate was incubated at $4{ }^{\circ} \mathrm{C}$ for 18 hours in moist-chamber. The plate used for IgG-Elisa was Nunclon Surface (Nunc) and for IgM-Elisa was Immulon 2 (Dynex ${ }^{\oplus}$-Dynex Technologies Inc., Virginia, USA).

Between the various reaction phases the microplates were submitted to three washings of one minute each with $0.01 \mathrm{M} \mathrm{PBS}$, $\mathrm{pH} 7.4$, containing $0.05 \%$ Tween 20 (PBS-Tween). Test sera and positive and negative reference sera were assayed in duplicate at $1 / 100$ and $1 / 200$ dilutions (IgM-Elisa and IgG-Elisa, respectively) in diluent buffer (PBS-Tween with 5\% normal rabbit serum added). The following conjugates were used: IgG-ELISA: anti-monkey IgG conjugated to alkaline phosphathase at a 1:30.000 dilution (Sigma); IgM-ELISA: anti-monkey IgM labeled to peroxidase, at a 1:1000 dilution (KPL). The substrates paranitrofenilphosphate (pNPP, Sigma-Aldrich, St. Louis, USA) and peroxidase solution $\left(\mathrm{H}_{2} \mathrm{O}_{2}\right)$ in ABTS System (2,2'-azino-bis 3-benzthiazoline-6-sulfonic acid) were allowed to react for 45 and 15 minutes respectively, at room temperature. The reading was taken in an ELISA reader (Dynex) equipped with a 450 and $405 \mathrm{~nm}$ filters.

The mean absorbance values of the sera were divided into ELISA levels (EL), which ranged from 0 to 9. The maximum limit of 0 was determined by the mean absorbance values of the negative animals $(\mathrm{n}=10)$ for T. gondii, +2 SD. Starting from this limit, the intervals between the other ELISA levels were defined through the addition of $35 \%$, as proposed by Machado et al. (1997) for the Babesia sp (Table 1).

\section{Histopathologic examination}

After 102 days of infection, the animals were euthanized according to the 2000 Report of the American Veterinary Medical Association (AVMA) on euthanasia and submitted to post-mortem

Table 1. Distribution of ELISA levels (EL) and the respective optic densities (OD) obtained for the Cebus apella experimentally infected by Toxoplasma gondii through IgM and IgG ELISA in Jaboticabal, São Paulo, Brazil

\begin{tabular}{ccc}
\hline EL & IgG/OD ELISA & IgM/OD \\
\hline ELISA & & \\
\hline 0 & $0.000-0.098$ & $0.000-0.100$ \\
1 & $0.099-0.134$ & $0.101-0.136$ \\
2 & $0.135-0.182$ & $0.137-0.184$ \\
3 & $0.183-0.247$ & $0.185-0.250$ \\
4 & $0.248-0.335$ & $0.251-0.339$ \\
5 & $0.336-0.453$ & $0.340-0.459$ \\
6 & $0.454-0.613$ & $0.460-0.621$ \\
7 & $0.614-0.828$ & $0.622-0.840$ \\
8 & $0.829-1.119$ & $0.841-1.135$ \\
9 & $\geq 1.120$ & $\geq 1.136$ \\
\hline
\end{tabular}

examination. Fragments were collected from the majority of organs, fixed in $10 \%$ buffered formalin, embedded in paraffin wax, sectioned at 4-6 $\mu \mathrm{m}$, and stained with haematoxylin and eosin (HE).

\section{Immunohistochemistry}

The streptavidin-biotin peroxidase method (Hsu et al., 1981) was used. Liver, kidney, spleen, lung, and brain sections were incubated overnight at room temperature with anti- $T$. gondii primary antibody (Dako Corporation, Carpinteria, USA) at a 1:10.000 dilution. The secondary biotinylated antibody and the streptavidin-biotin peroxidase complex were used at a 1:400 dilution with the Kit Strept ABComplex HRP Duet, Mouse/ Rabbit (Dako Corporation, Carpinteria, USA)

\section{Statistical analysis}

Indirect ELISA and IFA were compared through the nonparametrical chi-squared test at 5\% probability level.

\section{Results}

\section{Clinical toxoplasmosis}

During the first two days of infection, the three infected animals showed apathy, lack of appetite, and abdominal distention. After three days these clinical signs could not be observed. One of the animals showed apathy and sneezing at the beginning and was treated with sulfadiazine $\left(100 \mathrm{mg} \cdot \mathrm{kg}^{-1} /\right.$ day $)$ for three days, presenting remission of the clinical signs.

\section{Humoral immune response of experimental infection}

Serology results demonstrated that the experimentally infected animals presented a similar pattern of humoral immune response in IgG-IFA and IgM-IFA (Figure 1). Antibodies of value diagnosis were first detected at day 9 of infection in IFA (IgG and $\operatorname{IgM}$ ), with the difference that in IgG-IFA they continued to be detected until the end of the experiment and in IgM-IFA the antibodies were only detected up to day 13 PI. The highest titer (1/20480) was detected at day 31 PI (IgG-IFA) and at day 102 PI. In IgMIFA, the highest titer $(1 / 640)$ was detected at day 13 PI, with no subsequent detection of $\operatorname{IgM}$ antibodies through this technique. IgG and IgM antibodies anti- $T$. gondii from control animals were not detected through IFA during the experiment.

Using Elisa-Test IgG antibodies of value diagnosis $(\mathrm{EL} \geq 3)$ were detected at day 9 PI, in two animals, and at day 13 PI in the third animal. All animals presented similar humoral immune response at day $9 \mathrm{PI}$, presenting increasing titers until the end of the experiment (Figure 2). The highest value obtained in IgGELISA was corresponding to $\mathrm{EL}=8$. Levels of $\operatorname{IgM}$ antibodies $(E L \geq 3)$ were detected starting from day $3 \mathrm{PI}$ in two animals and starting from day 9 PI in the third animal. All animals presented similar behavior in relation to the IgM levels. The highest value obtained in IgM-ELISA was EL $=5$. 
IgG-IFA
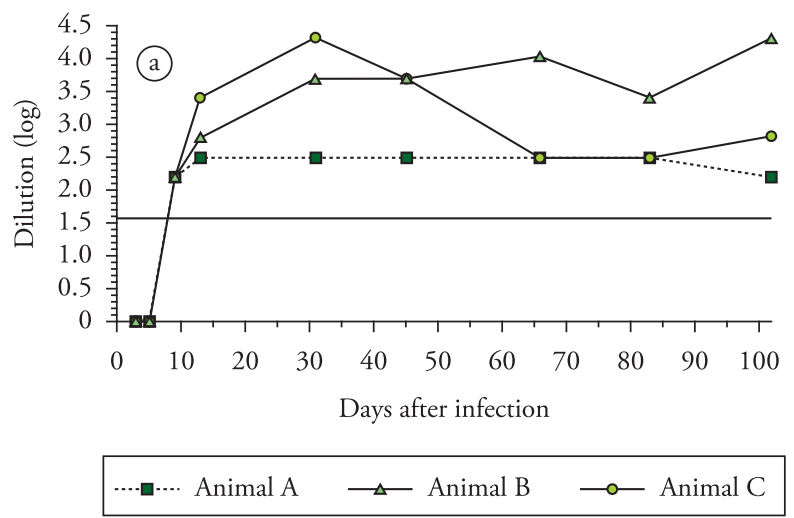

IgM-IFA

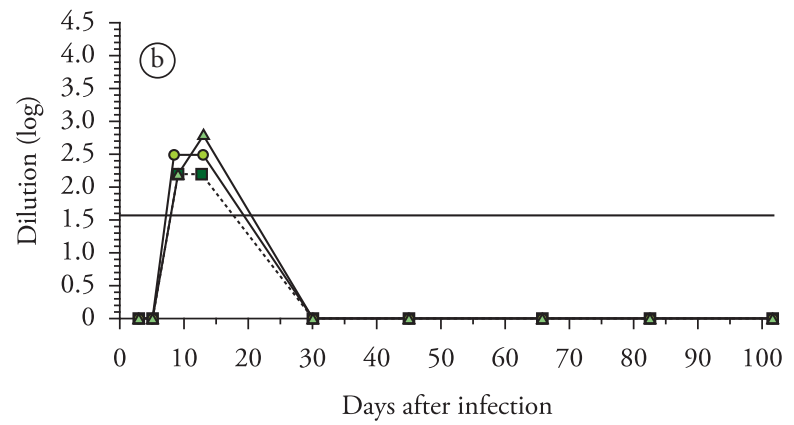

…-... Animal A $\longrightarrow$ Animal B $\multimap$ Animal C

Figure 1. Kinetics of humoral immune response of Cebus apella experimentally infected with $T$. gondii, using Indirect Fluorescence Assay (IFA) for IgG and IgM (log 2 dilution). The straight line (1.6) represents the cut-off.

\section{Humoral immune response of natural infection (T. gondii and N. caninum)}

From the naturally infected animals ( $\mathrm{n}=209), 64.59 \%$ were positive in IgG-IFA and IgG-ELISA seropositives were $67.94 \%$, presenting no significant difference between them. IgM-ELISA detected seropositivity in $52.63 \%$ of the sera, while IgM-IFA detected in only $0.96 \%$, presenting high significant difference $(\mathrm{p} \leq 0.05)$.

Figure 3 shows the distribution of the 209 sera of primates naturally infected with $T$. gondii considering the final dilution for IgM and IgG using IFA, and Figure 4 shows the distribution of the same sera considering the ELISA levels (EL) obtained for IgG and IgM, using indirect ELISA test. Seroprevalence by gender of primates is shown in Table 2 .

IFA for Neospora caninum revealed that $29.2 \%(n=61)$ of the animals in zoos from the State of São Paulo are serologically positive for this parasite. Among them 60 were also positive for Toxoplasma.

\section{Macroscopic and histologic findings and immunohistochemistry}

Macroscopically, the three infected primates presented hyperplasia of white pulp and splenomegaly. One of them presented
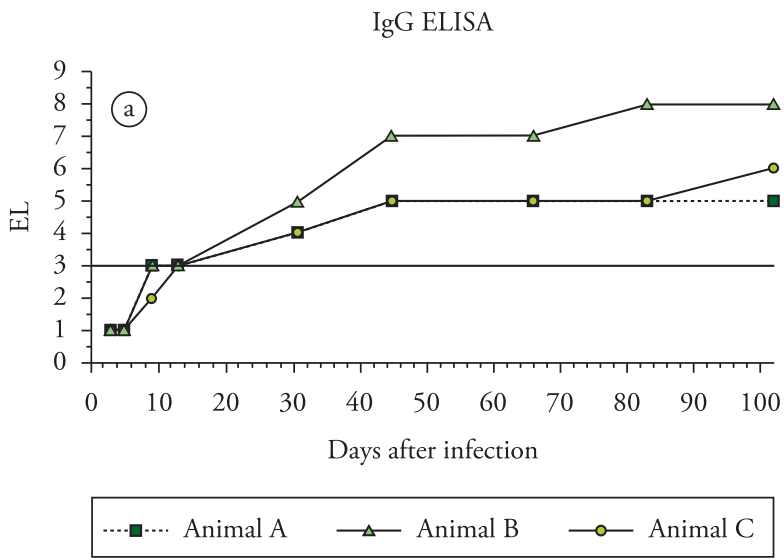

IgM ELISA

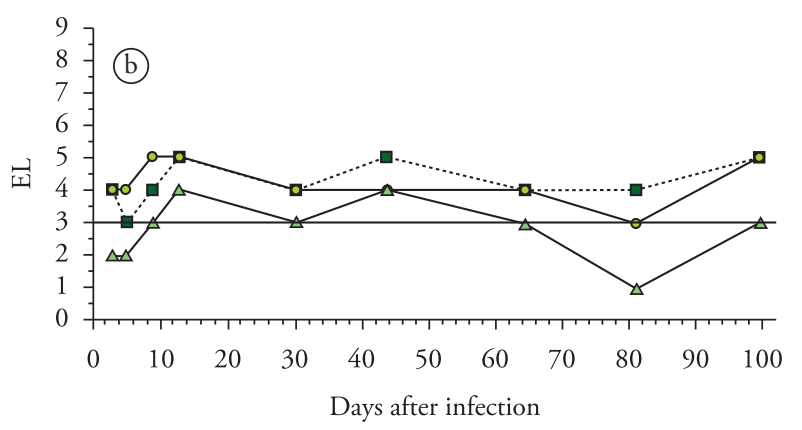

$\square$ Animal A Animal B $\longrightarrow$ Animal C

Figure 2. Kinetics of humoral immune response of Cebus apella experimentally infected with $T$. gondii, using indirect ELISA test (IgM and IgG). The straight line (3.0) represents the cut-off.

kidney congestion and other presented intestinal ulcer. Other macroscopic toxoplasmosis lesions were not observed.

Unremarkable interstitial pneumonia in the three infected animals was microscopically observed. One of them presented foci of inflammatory cells (polymorphonuclear) in the stomach, enteritis, unremarkable diffuse colitis, splenitis, and hyperplasia of white pulp in the spleen. Another primate presented focal liver necrosis, with predominance of polymorphonuclear cells. The kidney of this animal presented glomerular congestion and acute glomerulonephritis.

The immunohistochemistry did not reveal the presence of Toxoplasma in the infected animals.

\section{Discussion}

Toxoplasmosis is one of the most important zoonosis of almost all warm-blooded animals, and neotropical primates are among the susceptible animals (DUBEY; BEATTIE, 1988; EPIPHANIO, 2000).

The clinical signs observed in the primates experimentally infected, such as apathy, lack of appetite, and abdominal distension as well as vomiting, dyspnea, and diarrhea, were also observed by 


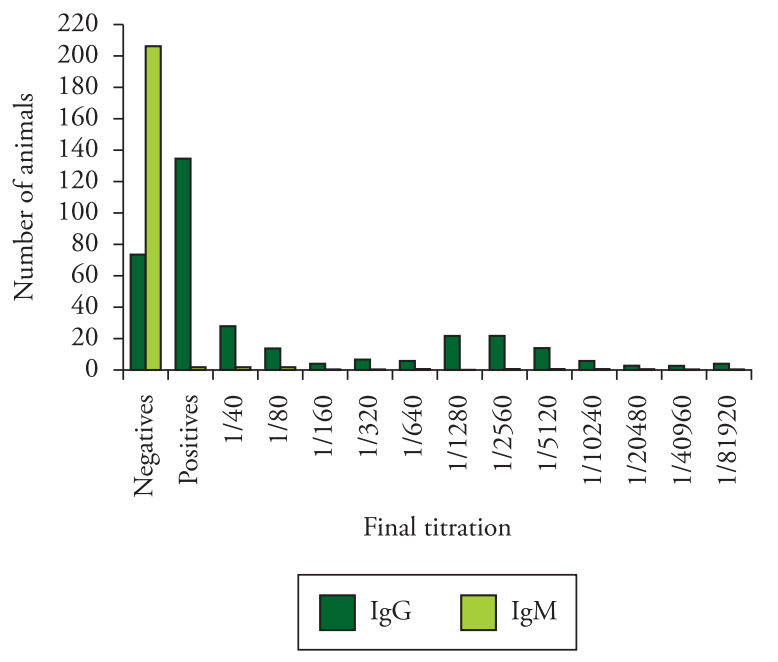

Figure 3. Distribution of the number of sera of primates $(n=209)$ naturally infected with $T$. gondii considering the final dilution for IgM and IgG using IFA.

Table 2. Prevalence of $T$. gondii antibodies in captive primates from different zoos in the state of São Paulo, Brazil

\begin{tabular}{lccc}
\hline $\begin{array}{c}\text { Gender of } \\
\text { primates }\end{array}$ & $\begin{array}{c}\text { No. of samples } \\
\text { examined }\end{array}$ & $\begin{array}{c}\text { No. of positive } \\
\text { samples }\end{array}$ & $\begin{array}{c}\text { Percent positive } \\
\text { (\%) }\end{array}$ \\
\hline Cebus sp & 105 & 83 & 79.0 \\
Callithrix sp & 42 & 12 & 26.2 \\
Alouatta sp & 20 & 10 & 50.0 \\
Leontopithecus sp & 15 & 3 & 20.0 \\
Ateles sp & 7 & 4 & 57.14 \\
Saimiri sp & 6 & 2 & 33.33 \\
Saguinus sp & 5 & 0 & 0 \\
Aotus sp & 3 & 2 & 66.66 \\
Erythrocebus sp & 3 & 3 & 100.0 \\
Lagothrix sp & 3 & 0 & 0 \\
Total & 209 & 119 & 56.9 \\
\hline
\end{tabular}

other authors (CUNNINGHAM et al., 1992; JUAN-SALLÉS et al., 1998; BOUER et al., 1999). However, some authors described cases of natural toxoplasmosis in neotropical primates that died without any clinical sign of the disease (DIETZ et al., 1997; PERTZ; DUBIELZIG; LINDSAY, 1997; EPIPHANIO et al., 2003).

The IFA employed in our experiment showed that for the experimentally infected animals, antibodies were detected from day 9 PI until day 13 PI in IgM-IFA. Carvalho (1998), studying the humoral response of felids infected with $T$. gondii, showed by using IFA that antibodies of IgM class appeared at day 7 PI and the presence of antibodies reached maximum titer in the interval of 16 to 22 days PI.

Our data show that ELISA is a sensitive serological test, able to detect low antibody titers in recent infections as well as over long periods of time, as we could detect antibodies for both IgG and IgM until the end of the experiment. Lappin et al. (1989), studying cats, showed that titers of antibodies from the $\mathrm{IgG}$ class develop between 2 to 4 weeks and usually remain positive for

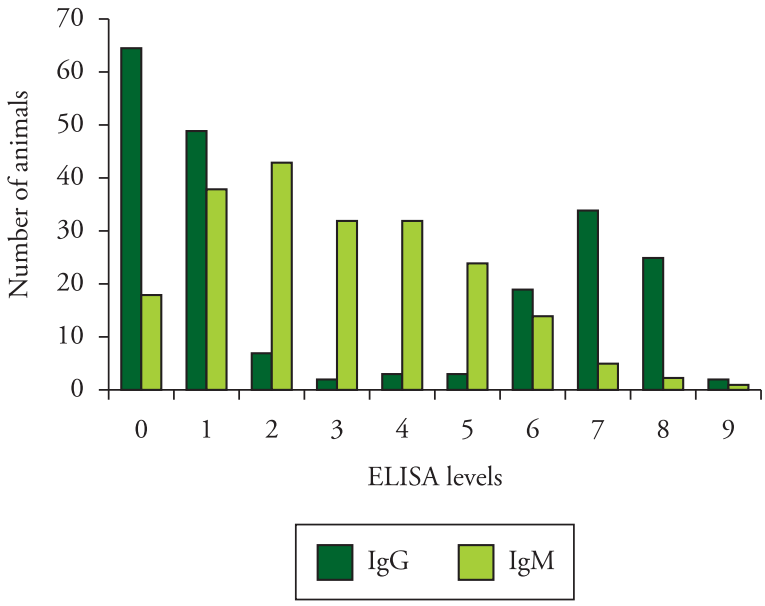

Figure 4. Distribution of the number of sera of primates naturally infected with $T$. gondii considering the ELISA levels (EL) obtained for $\operatorname{IgG}$ and $\mathrm{IgM}$, using indirect ELISA test.

months to years, while positive IgM titers appear in 2 to 3 weeks and become negative after 16 weeks of infection.

The detection of IgM and IgG anti- $T$. gondii antibodies in naturally infected primates revealed that the ELISA test is more sensitive than IFA in detecting the parasite, and the results allow us to conclude that there was no significant difference when the IgG class was studied, regardless of the test used, but when the IgM class was studied, the ELISA was shown to be much more sensitive than IFA, with significant difference between them.

The percentage of positive primates in this study is similar to the results obtained by Ferraroni and Marzochi (1980), who found $63.27 \%$ of free-living primates (Saimiri sp) positive for T. gondii by indirect hemaglutination in the Amazon region. In another survey performed by Dubey and Beattie (1988), 15.38\% of Cebus apella and $17.64 \%$ of capuchin monkeys presented positive titers for toxoplasmosis, by the Sabin-Feldman test, both in natural infections. McConnell et al. (1973) found $11.7 \%$ of Papio cynocephalus and $100 \%$ of captive Saimiri sp positive for T. gondii through IFA.

The fact that 60 out of the 61 monkeys were positive for Neospora caninum and T. gondii indicates that the animals presented antibodies for the two parasites because, according to Dubey and Lindsay (1996), the cross-reaction between these two parasites using IFA for the detection of antibodies anti- $N$. caninum is minimum or absent. IgG anti- $N$. caninum antibodies were not detected in the experimental group.

At necropsy, splenomegaly was the most significant finding observed in the infected animals. In literature, besides this finding, intestinal hemorrhage, hepatomegaly, edema and pulmonary congestion, and enlarged mesenteric lymphonodes were described (DIETZ et al., 1997; PERTZ; DUBIELZIG; LINDSAY, 1997; JUAN-SALLÉS et al., 1998; BOUER et al., 1999; EPIPHANIO et al., 2003). The fact that tissue cysts were not detected in the musculature or in the analyzed organs could be related to the strain, which was acystogenic. Nery-Guimarães and Franken (1971) infected primates of the New and Old World and 
no macroscopic alterations were observed due to toxoplasmosis. The most common microscopic findings of toxoplasmosis in naturally infected primates are edema, congestion and lung necrosis, necrotic and hemorrhagic enteritis, intestinal ulcers, hemorrhagic lymphonodes, necrotic hepatitis, spleen hyperplasia, inflammation of the meninges, cerebellar hemorrhage (JUAN-SALLÉS et al., 1998), presence of tachyzoites in the brain and lymphonodes (DIETZ et al., 1997; JUAN-SALLÉS et al., 1998), in the intestine, liver, and lung (PERTZ; DUBIELZIG; LINDSAY, 1997; BOUER et al., 1999), and the kidneys and spleen (BOUER et al., 1999). Besides these findings, acute interstitial pneumonia, lymphadenitis, splenitis, and multifocal ulcerative enteritis have been observed (EPIPHANIO et al., 2000).

Although $T$. gondii was not detected in the tissues of the infected primates by immunohistochemistry, some authors have confirmed the presence of tachyzoites in natural infections (DIETZ et al., 1997; JUAN-SALLÉS et al., 1998; BOUER et al., 1999; EPIPHANIO et al., 2000).

Finally, we may conclude that neotropical primates are susceptible to toxoplasmosis, and the prevalence of seropositive primates for this disease is high in the zoological gardens of the state of Sao Paulo. The prevention of toxoplasmosis in New World primates requires knowledge of the disease's epidemic chain. Correct handling, daily cleaning of the facilities, and control of feeding are essential measures for the prevention and control of this disease in captivity.

\section{Acknowledgements}

The authors are grateful to the staff, keepers, veterinarians, and biologists at the zoos.

\section{References}

ANDERSON, D. C.; MCCLURE, H. M. Toxoplasmosis. In: JONES, T. C.; MOHR, V.; HUNT, R. D. (Eds.). Monographs on pathology of laboratory animals: nonhuman primates. New York: Springer-Verlag, 1993. p. 63-69.

BOUER, A. et al. Outbreak of Toxoplasmosis in Lagothrix lagotricha. Folia Primatologica, v. 70, n. 5, p. 282-285, 1999.

CALAMEL, M.; LAMBERT, M. ELISA: elaboration dun modéle mathématique informatisé pour l expression du sérodiagnostic de la toxoplasmose uen U.I. Revue de Médecine Véterinaire., v. 136, n. 6, p. 295-302, 1985.

CAMARGO, M. E.; MOURA, M. E. G.; LESER, P. G. Toxoplasmosis Serology: an efficient hemagglutination procedure to detect $\operatorname{IgG}$ and $\operatorname{IgM}$ antibodies. Revista do Instituto de Medicina Tropical de Sáo Paulo, v. 31, n. 4, p. 279-285, 1989.

CARME, B. et al. Outbreaks of toxoplasmosis in a captive breeding colony of squirrel monkeys. Veterinary Parasitology, v. 163, n. 1-2, p. 132-135, 2009

CARVALHO, C. S. Padronização do ELISA teste para a detecçáo de anticorpos das classes IGM e IGC em soros de gatos experimentalmente infectados com taquizoítos de T. gondii. 1998. Dissertação (Mestrado) - Universidade Estadual Paulista - UNESP, Jaboticabal.

CUNNINGHAM, A. A.; BUXTON, D.; THOMSON, K. M. An epidemic of Toxoplasmosis in a captive colony of Squirrel monkeys (Saimiri sciureus). Journal of Comparative Pathology, v. 107, n. 2, p. 207-219, 1992.

DIETZ, H. H. et al. Toxoplasmosis in a colony of New World monkeys. Veterinary Parasitology, v. 68, n. 4, p. 299-304, 1997.
DOMINGUES, L. M. et al. Canine Toxoplasmosis: a comparative evaluation of the detection of anti-Toxoplasma gondii antibodies by the indirect immunoenzymatic assay (ELISA) and the indirect immunofluorescence reaction (IFF). Revista Brasileira de Parasitologia Veterinária, v. 4, n. 2, p. 79-85, 1998.

DUBEY, J. P.; KRAMER, L. W.; WEISBRODE, S. E. Acute death associated with Toxoplasma gondii in Ring-tailed lemurs. Journal American Veterinary Medical Association, v. 187, n. 11, p. 1272-1273, 1985.

DUBEY, J. P. Toxoplasmosis. Journal American Veterinary Medical Association, v. 189 , n. 2, p. 166-170, 1986.

DUBEY, J. P.; BEATTIE, C. P. Toxoplasmosis of animals and man. Florida: CRC Press, 1988. 220 p.

DUBEY, J. P.; LINDSAY, D. S. A review of Neospora caninum and neosporosis. Veterinary Parasitology, v. 67, n. 1-2, p. 1-59, 1996.

EPIPHANIO, S. et al. Toxoplasmosis in golden-headed lion tamarins (Leontopithecus chrysomelas) and emperor marmosets (Saguinus imperator) in captivity. Journal of Zoo and Wildlife Medicine, v. 31, n. 2, p. 231-235, 2000.

EPIPHANIO, S. et al. Toxoplasmosis in a wild caught black lion tamarin (Leonthopithecus chrysopygus): short communication. Veterinary Record, v. 149, n. 20, p. 627-628, 2001.

EPIPHANIO, S.; SINHORINI, I. L.; CATÃO-DIAS, J. L. Pathology of Toxoplasmosis in Captive New World Primates. Journal of Comparative Pathology, v. 129, n. 2-3, p. 196-204, 2003.

FERRARONI, J. J.; MARZOCHI, M. C. A. Prevalência da infecçăo pelo Toxoplasma gondii em animais domésticos, silvestres e grupamentos humanos da Amazônia. Memórias do Instituto Oswaldo Cruz, v. 75, n. 1-2, p. 99-109, 1980.

HARTREE, E. F. Determination of protein: a modification of the lowry method that gives a linear photometric response. Analytical Biochemistry, v. 48, n. 2, p. $422-427,1972$.

ISHIZUKA, M. M.; MIGUEL, O.; BROGLIATO, D. F. Prevalência de anticorpos anti-toxoplasma em soros de cáes no município de São Paulo. Revista da Faculdade de Medicina Veterinária e Zootecnia, v. 11, p. 115-125, 1974.

JUAN-SALLÉS, C. et al. Fatal acute toxoplasmosis in three golden lion tamarins (Leontopithecus rosalia). Journal of Zoo and Wildlife Medicine, v. 29, n. 1, p. 55-60, 1998.

LAPPIN, M. R. et al. Enzyme-linked immunosorbent assay for the detection of circulating antigens of Toxoplasma gondii in the serum of cats. American Journal Veterinary Research, v. 50, n. 9, p. 1586-1590, 1989.

MACHADO, R. Z. et al. An enzyme-linked immunosorbent assay (ELISA) for the detection of antibodies against Babesia bovis in cattle. Veterinary Parasitology, v. 71 , n. 1 , p. $17-26,1997$.

MCCONNELL, E. E. et al. Toxoplasmosis in free-ranging chacma baboons (Papio ursinus) from the Kruger National Park. Transactions of the Royal Society of Tropical Medicine and Hygiene, v. 67, n. 6, p. 851-855, 1973.

NERY-GUIMARÃES, F.; FRANKEN, A. J. Toxoplasmose em primatas não humanos. II. Tentativas de infecçôes experimentais em Macacca mulatta, Cebu apella e Callithrix jacchus e pesquisa de anticorpos em várias espécies de platyrrhinus. Memórias do Instituto Oswaldo Cruz, v. 69, n. 2, p. 97-111, 1971.

PERTZ, C.; DUBIELZIG, R. R.; LINDSAY, D. S. Fatal Toxoplasma gondii infection in golden lion tamarins (Leontopithecus rosalia rosalia). Journal of Zoo and Wildlife Medicine, v. 28, n. 4, p. 491-493, 1997.

SALANT, $\mathrm{H}$ et al. An outbreak of Toxoplasmosis amongst squirrel monkeys in an Israeli monkey colony. Veterinary Parasitology, v. 159, n. 1, p. 24-29, 2009.

SILVA, J. C. R. et al. Seroprevalence of Toxoplasma gondii in captive neotropical felids from Brazil. Veterinary Parasitology, v. 102, n. 3, p. 217-224, 2001.

VIDOTTO, O. Toxoplasmose: epidemiologia e importância da doença na saúde animal. Semina: Ciência Agrária, v. 13, n. 1, p. 69-75, 1992. 